\title{
Interstitial Cells of Cajal Mediate Cholinergic Neurotransmission from Enteric Motor Neurons
}

\author{
Sean M. Ward, Elizabeth A. H. Beckett, XuanYu Wang, Fred Baker, Mohammad Khoyi, and \\ Kenton M. Sanders \\ Department of Physiology and Cell Biology, University of Nevada School of Medicine, Reno, Nevada 89557
}

Interstitial cells of Cajal (ICC) are interposed between enteric neurons and smooth muscle cells in gastrointestinal muscles. The role of intramuscular ICC (IC-IM) in mediating enteric excitatory neural inputs was studied using gastric fundus muscles of wild-type animals and $W / W^{\vee}$ mutant mice, which lack IC-IM. Excitatory motor neurons, labeled with antibodies to vesicular acetylcholine transporter or substance-P, were closely associated with IC-IM. Immunocytochemistry showed close contacts between enteric neurons and IC-IM. IC-IM also formed gap junctions with smooth muscle cells. Electrical field stimulation yielded fast excitatory junction potentials in the smooth muscle that were blocked by atropine. Neural responses were greatly reduced in muscles of $W / W^{v}$ animals. Loss of cholinergic responses in $W / W^{v}$ muscles seemed to be caused by the loss of close synaptic contacts between motor neurons and IC-IM, because these muscles were not less responsive to exogenous acetylcholine than were wild-type muscles. $W / W^{\vee}$ muscles also responded to excitatory nerve stimulation when the breakdown of acetylcholine was blocked by neostigmine. The density of cholinergic nerve bundles within the muscles was not significantly different in wild-type and $W / W^{\vee}$ muscles, and similar amounts of ${ }^{14}[\mathrm{C}]$ choline were released from preloaded wildtype and $W / W^{v}$ muscles in response to nerve stimulation. The impact of losing IC-IM on gastric compliance was also evaluated in intact stomachs. Pressure increased as a function of fluid volume and infusion rate in wild-type animals, but $W / W^{v}$ animals showed little basal tone and minimal increases in pressure with fluid infusions. These data suggest that IC-IM play a major role in receiving cholinergic excitatory inputs from the enteric nervous system in the murine fundus.

Key words: interstitial cells of Cajal; enteric nervous system; cholinergic neurotransmission; neuromuscular junction; acetylcholinesterase; gastrointestinal tract
Enteric neurons that contain acetylcholine (ACh) and tachykinins provide excitatory motor input to the gastrointestinal (GI) tract. Most of these neurons have cell bodies within the myenteric plexus and send varicose processes into the tunica muscularis where it is thought that they release transmitter within tens of nanometers of target cells. Ultrastructural studies of neural projections to the longitudinal muscle of the guinea pig ileum from nerves of the tertiary plexus showed close associations between varicosities and longitudinal muscle cells, and three-dimensional reconstructions demonstrate neuromuscular-like structures (K1emm, 1995). In the deep muscular plexus of the guinea pig small intestine, however, many motor neurons, inhibitory and excitatory, form close associations with interstitial cells of Cajal (ICC) (Wang et al., 1999), suggesting that ICC may be involved in the mediation of neurotransmission (Ramon y Cajal, 1911; Daniel and Posey-Daniel, 1984; Sanders, 1996).

ICC express c-kit and depend on signaling via Kit receptors for development and maintenance of phenotype (Maeda et al., 1992; Ward et al., 1994; Torihashi et al., 1995). Kit expression has provided an important means of identifying ICC and understand-

Received Sept. 8, 1999; revised Nov. 10, 1999; accepted Nov. 23, 1999.

This work was supported by National Institutes of Health Grant DK 40569. The Morphology Core Laboratory supported by Program Project Grant DK 41315 was used for the immunohistochemical studies. Choline release studies and M.K. were supported by National Institutes of Health Grant HL 38126 to Dr. D. P Westfall. We are grateful to Julia R. Bayguinov for excellent technical assistance and to Dr. P. C. Emson of the Molecular Neuroscience Group (Cambridge, U.K.) for providing us with the NOS antibody.

Correspondence should be addressed to Dr. S. M. Ward at the above address. E-mail: sean@physio.unr.edu.

Copyright () 2000 Society for Neuroscience $0270-6474 / 00 / 201393-11 \$ 15.00 / 0$ ing the anatomical distribution of ICC in GI muscles. Blockade of Kit receptors (Torihashi et al., 1995, 1999; Ward et al., 1997; Ordog et al., 1999) and use of c-kit mutant animals (Ward et al., 1994; Huizinga et al., 1995; Burns et al., 1996) have proven to be valuable experimental manipulations to determine the physiological role of ICC. For example, animals that lack intramuscular ICC have profoundly reduced enteric inhibitory responses, supporting a role for ICC in neurotransmission (Burns et al., 1996; Ward et al., 1998).

Recent morphological studies have also documented important anatomical associations between ICC and excitatory motor neurons. Excitatory motor neurons in the deep muscular plexus of the guinea pig small intestine (IC-DMP) appear to be as closely aligned with IC-DMP as inhibitory motor neurons (Wang et al., 1999). IC-DMP also express neurokinin 1 (NK1) receptors for tachykinins (Sternini et al., 1995; Grady et al., 1996; Portbury et al., 1996; Young et al., 1996; Vannucchi et al., 1997), and when stimulated with fluorescently tagged substance-P, IC-DMP internalize NK1 receptors (Lavin et al., 1998). Thus, these cells express the structural and molecular components that would facilitate a role in excitatory neurotransmission. In the present study we have explored the morphological relationship between excitatory motor neurons and intramuscular ICC (IC-IM) in the murine fundus. Using Kit mutant animals that lack IC-IM, we have tested the importance of these cells in cholinergic motor inputs to the proximal stomach. We have also found that lesions in IC-IM cause dramatic changes in gastric compliance that could be analogous to some clinical disorders of gastric motility. 
Table 1. Details of antibodies used for immunohistochemistry

\begin{tabular}{|c|c|c|c|c|}
\hline Combined antibodies (fixative) & Resource & $\begin{array}{l}\text { Monoclonal or polyclonal } \\
\text { antibodies }\end{array}$ & Host & Dilution \\
\hline ACK2/anti-NOS (acetone fixed) & $\begin{array}{l}\text { Life Technologies, Gaithersburg, MD/Dr. } \\
\text { Piers Emson, Molecular Neuroscience } \\
\text { Group, Cambridge, UK }\end{array}$ & Monoclonal/polyclonal & Rat/sheep & $1: 200 / 1: 200$ \\
\hline ACK2/anti-vAChT (acetone fixed) & Life Technologies/Chemicon, Temecula, CA & Monoclonal/polyclonal & Rat/goat & $1: 200 / 1: 200$ \\
\hline $\begin{array}{l}\text { Anti-VIM/anti-Sub-P (paraformal- } \\
\text { dehyde fixed) }\end{array}$ & $\begin{array}{l}\text { Polysciences, Warrington, PA/Incstar, Still- } \\
\text { water, MN }\end{array}$ & Polyclonal/polyclonal & Goat/rabbit & $1: 100 / 1: 200$ \\
\hline
\end{tabular}

ACK2, Anti-c-Kit; NOS, nitric oxide synthase; Sub-P, substance-P; vAChT, vesicular acetylcholine transporter; VIM, vimentin.

\section{MATERIALS AND METHODS}

\section{Animals}

Heterozygote animals $(W /+)$ and $\left(W^{\mathrm{v}} /+\right)$ were obtained from The Jackson Laboratory (Bar Harbor, ME) and paired to obtain $+/+, W /+$, $W^{\mathrm{v}} /+, W / W^{\mathrm{v}}$, and $W^{\mathrm{v}} / W^{\mathrm{v}}$ offspring. Wild-type $(+/+$; black coats) and $W / W^{v}$ (pure white coats) mice, between the ages of 20 and $30 \mathrm{~d}$ postpartum, were anesthetized by chloroform inhalation and exsanguinated by cervical dislocation followed by decapitation. The use and treatment of animals were approved by the Institutional Animal Use and Care Committee at the University of Nevada.

The entire stomach, including portions of the esophagus and duodenum, was removed and placed in Krebs-Ringer buffer (KRB, see below for composition). For electrophysiological and isometric force measurements, stomachs were opened along the lesser curvature from the most proximal regions of the fundus through to the corpus. Luminal contents were washed with $\mathrm{KRB}$, and the mucosa was removed, revealing the underlying circular muscle layer of the gastric fundus.

\section{Morphological studies}

Immunohistochemistry. Whole-mount tissues of the gastric fundus from wild-type and $W / W^{v}$ animals were fixed in either acetone $\left(10 \mathrm{~min}\right.$ at $\left.4^{\circ} \mathrm{C}\right)$ or paraformaldehyde $\left(4 \% \mathrm{w} / \mathrm{v}\right.$ in $0.1 \mathrm{M}$ PBS for $20 \mathrm{~min}$ at $\left.4^{\circ} \mathrm{C}\right)$. After fixation, tissues were preincubated in bovine serum albumin for $1 \mathrm{hr}(1 \%$ in PBS) before being incubated in a combination of primary antibodies (see Table 1). Tissues were incubated overnight at $4^{\circ} \mathrm{C}$ in primary antibodies. For double-label immunostaining, the first incubation was performed for $48 \mathrm{hr}$ at $4^{\circ} \mathrm{C}$ with a mixture of two primary antisera raised in different species. The three combinations of antibodies used were rat and sheep, rat and goat, and goat and rabbit (see Table 1). For antibody combinations, the mixtures of labeled secondary antibodies were labeled with fluorescein isothiocyanate (FITC) and Texas Red. All secondary antibodies were purchased from Vector Laboratories (Burlingame, CA) and diluted to 1:100 in PBS. Secondary incubations were performed for $1 \mathrm{hr}$ at room temperature. Control tissues were prepared by omitting either primary or secondary antibodies from the incubation solutions. All the antisera were diluted with $0.3 \%$ Triton X-100 in 0.01 M PBS, pH 7.4. Tissues were examined with a Bio-Rad MRC 600 confocal microscope (Hercules, CA) with an excitation wavelength appropriate for FITC (494 $\mathrm{nm})$ and Texas Red $(595 \mathrm{~nm})$. Confocal micrographs are digital composites of Z-series scans of 10-15 optical sections through a depth of 6-40 $\mu \mathrm{m}$. Final images were constructed with Bio-Rad Comos software.

Immunocytochemistry. Gastric tissues were prepared for immunocytochemistry by fixation in paraformaldehyde $(4 \% \mathrm{w} / \mathrm{v})$, glutaraldehyde $(0.05 \% \mathrm{v} / \mathrm{v})$, and picric acid $(0.2 \% \mathrm{v} / \mathrm{v})$ made up in $0.1 \mathrm{M}$ phosphate buffer (PB) at $\mathrm{pH} 7.4$ for $45 \mathrm{~min}$ at room temperature (Somogyi and Takagi, 1982). After a brief rinse in $0.1 \mathrm{M} \mathrm{PB}$, tissues were washed at room temperature in several changes of $50 \%$ ethanol in distilled water until the picric acid staining of the tissue had disappeared ( 20-30 min). The tissue was then washed in $0.1 \mathrm{M} \mathrm{PB}$ and incubated in $0.1 \% \mathrm{NaCNBH}_{3}$ (Aldrich, Milwaukee, WI) in $0.1 \mathrm{M} \mathrm{PB}$ for $30 \mathrm{~min}$ at room temperature. After washing in PB several times, the tunica muscularis was peeled from the remaining gut wall and cut into pieces $\sim 3 \times 3 \mathrm{~mm}$. After nonspecific binding was blocked with BSA $(1 \%)$ for $1 \mathrm{hr}$ at room temperature, the tissues were incubated overnight at room temperature in anti-vesicular acetylcholine transporter (anti-vAChT; 1:400) and anti-nitric oxide synthase (anti-NOS; 1:400) primary antisera. On the second day, after washing in PBS several times, secondary immunoreactions were performed with the Vectastain ABC kit (PK-4001; Vector Laboratories) using 3,3'-diaminobenzidine (DAB; $0.05 \%$ plus $0.01 \% \mathrm{H}_{2} \mathrm{O}_{2}$ in $0.05 \mathrm{M}$
Tris-buffered saline, $\mathrm{pH}$ 7.6) as a peroxidase substrate. Tissues were continuously checked under the light microscope for a suitable reaction, before being post-fixed in $1 \%$ osmium tetroxide in $0.1 \mathrm{M} \mathrm{PB}, \mathrm{pH} 7.4$, stained en bloc with 2\% aqueous uranyl acetate for 30-40 min, dehydrated, infiltrated, and embedded in Medcast resin (Electron Microscopy Sciences, Fort Washington, PA). Ultrathin sections were cut parallel to the circular muscle layer and stained with lead citrate for $10 \mathrm{~min}$ before viewing with a Philips CM10 transmission electron microscope.

\section{Physiological studies}

Electrical responses. After the mucosa was removed, strips of gastric fundus muscle $(6 \times 5 \mathrm{~mm})$ were cut and pinned to the Sylgard elastomere (Dow Corning) floor of a recording chamber with the mucosal side of the circular muscle facing upward. For electrical field stimulation of motor nerves, parallel platinum electrodes were placed on either side of the muscle strips. Circular muscle cells were impaled with glass microelectrodes filled with $3 \mathrm{M} \mathrm{KCl}$ and having resistances of 50-80 M $\Omega$. Transmembrane potentials were measured with a high-impedance electrometer [World Precision Instruments (WPI) duo 773; WPI, Sarasota, FL], and outputs were displayed on a Tektronix 2224 oscilloscope (Wilsonville, OR). Electrical signals were recorded on videotape (A. R. Vetter Company, Rebersburg, PA). Neural responses were elicited by square wave pulses of electrical field stimulation (0.1-0.75 msec duration; 1-100 $\mathrm{Hz}$ supramaximal voltage; Grass S48 stimulator; Quincy, MA).

Mechanical responses. Separate mechanical experiments were performed using standard organ-bath techniques. The mucosa was removed from the gastric fundus by sharp dissection, and strips of muscle $(\sim 6 \times$ $1.5 \mathrm{~mm}$ ) were isolated and attached to a fixed mount and to a Fort 10 isometric strain gauge (WPI). The muscles were immersed in organ baths maintained at $37 \pm 0.5^{\circ} \mathrm{C}$ with oxygenated KRB. A resting force of $300 \mathrm{mg}$ was applied, which was shown to set the muscles at optimum length (data not shown). This was followed by an equilibration period of $1 \mathrm{hr}$, during which time the bath was continuously perfused with oxygenated KRB. Neural responses were recorded as described under electrical responses. Signals were recorded onto a chart recorder (Gould RS 3600; Cleveland, $\mathrm{OH})$.

Whole-organ experiments. Whole-organ experiments were performed to examine the differences in gastric compliance of wild-type and $W / W^{\mathrm{v}}$ mutant animals. Animals had food removed $\sim 4$ hr before experiments were initiated to deplete gastric contents; access to water was not restricted. Stomachs with esophagus and proximal duodenum attached were isolated from age-matched wild-type and $W / W^{\mathrm{v}}$ animals. Each stomach had a single lined polyethylene tubing that was placed through the lower esophageal sphincter and the pylorus and that was tied to the muscle wall at both ends with suture thread to avoid fluid leakage. A 1-mm-diameter hole was placed in the tube before insertion and was situated approximately at the level of the fundus. At one end of the tube a pressure transducer was mounted, and the other end was connected to a variable-rate infusion pump. A standard volume $(200 \mu \mathrm{l})$ of Krebs' solution was infused into the stomachs at different rates (1.01-20.28 $\mu \mathrm{l}$ $\mathrm{sec}^{-1}$ ), and gastric pressure (centimeters of $\mathrm{H}_{2} \mathrm{O}$ ) was plotted as a function of infusion volume for each of five different infusion rates (average of three infusions for each rate). Gastric pressure was recorded under control conditions and after the addition of $\mathrm{N} \omega$-nitro-L-arginine (L-NA) $(100 \mu \mathrm{M})$ and atropine $(1 \mu \mathrm{M})$ for both wild-type and $W / W^{\mathrm{v}}$ animals.

Transmitter release studies. For each experiment, three gastric fundi from wild-type and $W / W^{\mathrm{v}}$ animals were prepared in a manner similar to that described for the electrophysiological studies. Tissues were secured between platinum plate electrodes and incubated at $37^{\circ} \mathrm{C}$ in modified 
Krebs' solution of the following composition (in $\mathrm{mm}$ ): $\mathrm{NaCl} 110, \mathrm{KCl} 4.6$, $\mathrm{CaCl}_{2} 2.5, \mathrm{NaHCO}_{3} 24.8, \mathrm{KH}_{2} \mathrm{PO}_{4} 1.2, \mathrm{MgSO}_{4} 1.2$, glucose 11, EDTA 0.03 , and ascorbic acid 0.06 , containing $\left[{ }^{14} \mathrm{C}\right]$ choline chloride $(1 \mu \mathrm{Ci} / \mathrm{ml})$, for $40 \mathrm{~min}$ in which tissues were continuously stimulated with electrical field stimulation (EFS; $1 \mathrm{msec}$ pulses at $1 \mathrm{~Hz}$ ). Tissues were then placed into $300 \mu \mathrm{l}$ perfusion chambers and superfused with Krebs' solution containing hemicholinium-3 $(10 \mathrm{~mm})$ at $37^{\circ} \mathrm{C}$ for $90 \mathrm{~min}(2 \mathrm{ml} / \mathrm{min})$. After $55 \mathrm{~min}$ of washing, the tissues were electrically stimulated $(5 \mathrm{~Hz}$; $0.1 \mathrm{msec}$ ) for $1 \mathrm{~min}\left(\mathrm{~S}_{1}\right)$, because preliminary experiments had demonstrated that the first stimulus evoked a very high overflow of $\left[{ }^{14} \mathrm{C}\right] \mathrm{ACh}$ compared with that seen with subsequent stimuli. After this washing period, the superfusate was collected for $175 \mathrm{~min}$ at $1 \mathrm{~min}$ intervals in 7 $\mathrm{ml}$ scintillation vials. The tissues were then stimulated at $40 \mathrm{~min}$ intervals $\left(\mathrm{S}_{2}, 95\right.$ th minute; $\mathrm{S}_{3}, 135$ th minute; $\mathrm{S}_{4}, 175$ th minute; $\mathrm{S}_{5}, 215$ th minute) for $1 \mathrm{~min}(5 \mathrm{~Hz} ; 0.1$-msec-duration pulses). In experiments in which the effects of L-NA, atropine, neostigmine, hexamethonium, and tetrodotoxin were examined, the drugs were allowed to equilibrate in the bathing medium for $20 \mathrm{~min}$ before stimulation. The $2 \mathrm{ml}$ samples of Krebs' solution were made up to $7 \mathrm{ml}$ with Ecolume scintillant (ICN Biomedicals, Cleveland, $\mathrm{OH}$ ) before being counted twice in a Beckman LS60001C scintillation counter for $3 \mathrm{~min}$; results were then averaged. The tissues were transferred to scintillation vials, solubilized overnight in $1 \mathrm{ml}$ of $10 \% \mathrm{NaOH}$, neutralized with $\mathrm{HCl}$, and buffered with HEPES before counting. Overflow of ${ }^{14} \mathrm{C}$ was calculated as a fractional release from the tissue. This technique has been used to study the release of $\mathrm{ACh}$ from a variety of neuroeffector preparations such as guinea pig GI tissues (Alberts et al., 1982).

Data are expressed as means \pm SEM from wild-type and $W / W^{v}$ mutant animals. Differences in the data were evaluated by Student's $t$ test; $p$ values $<0.05$ were taken as statistically significant. The $n$ values reported in the text refer to the number of animals used for each protocol.

A total of 40 wild-type and $30 \mathrm{~W} / \mathrm{W}^{\mathrm{v}}$ animals were used for physiological experiments, 16 wild-type and $8 \mathrm{~W} / \mathrm{W}^{\mathrm{v}}$ animals were used for morphological studies, and 15 wild-type and $15 \mathrm{~W} / \mathrm{W}^{\mathrm{v}}$ animals were used for transmitter release studies (i.e., five transmitter release experiments were performed using tissues from 3 wild-type and $3 \mathrm{~W} / \mathrm{W}^{\mathrm{v}}$ animals per experiment).

Solutions and drugs. Muscles were maintained in $\operatorname{KRB}\left(37.5 \pm 0.5^{\circ} \mathrm{C}\right)$, $\mathrm{pH} 7.3-7.4$, containing (in $\mathrm{mM}$ ): $\mathrm{Na}^{+} 137.4, \mathrm{~K}^{+} 5.9, \mathrm{Ca}^{2+} 2.5, \mathrm{Mg}^{2+} 1.2$, $\mathrm{Cl}^{-} 134, \mathrm{HCO}_{3}{ }^{-} 15.5, \mathrm{H}_{2} \mathrm{PO}_{4}{ }^{-} 1.2$, and dextrose 11.5 , bubbled with $97 \% \mathrm{O}_{2}$ and $3 \% \mathrm{CO}_{2}$. Acetylcholine, neostigmine bromide, atropine sulfate, tetrodotoxin, and L-NA (Sigma, St. Louis, MO) were dissolved in distilled water at $0.1-0.01 \mathrm{M}$ and diluted in KRB to the stated final concentrations.

\section{RESULTS}

\section{Morphological relationships between enteric motor neurons and IC-IM of the fundus}

Anti-c-Kit (ACK2) and vimentin antibodies were used to examine the distribution of interstitial cells of Cajal in the murine gastric fundus. Spindle-shaped, Kit-immunopositive cells were observed within the circular and longitudinal layers running parallel to the muscle fibers (Fig. $1 A-C$ ). Previous studies have shown that cells with this morphology in the murine fundus are IC-IM (Burns et al., 1996). IC-IM were absent in gastric fundus muscles of $W / W^{\mathrm{v}}$ mutants (Fig. $1 D-F$ ) (Burns et al., 1996). The relationship between enteric motor nerves and IC-IM was investigated in immunohistochemical studies using double labeling with an antibody to Kit (ACK2) and antibodies to either the vAChT, Sub-P, or NOS.

vAChT-like immunoreactivity revealed a dense network of nerve bundles within the circular and longitudinal muscle layers (Fig. $1 A ; 5.7 \pm 2.0$ bundles per $100 \mu \mathrm{m}$ cross section perpendicular to the axis of the circular muscle). Double labeling for vAChT and Kit revealed that nerve bundles containing vAChT-positive fibers were closely associated with IC-IM (Fig. 1A). Sub-Pimmunopositive nerve cell bodies were observed at the level of the myenteric plexus, and immunopositive nerve bundles were observed running within both muscle layers (e.g., $5.18 \pm 2.8$ bundles per random $100 \mu \mathrm{m}$ transecting line within the circular muscle
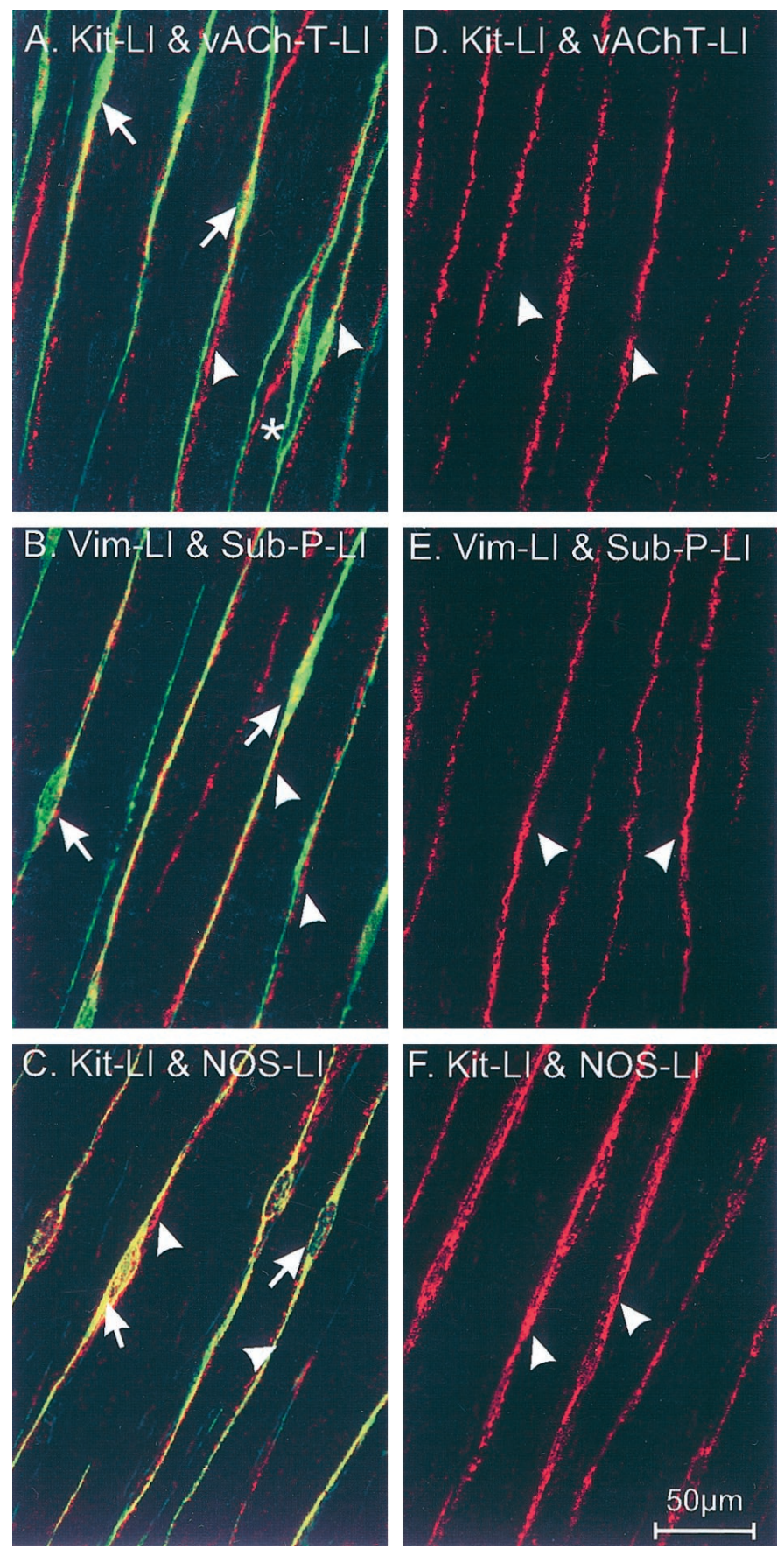

Figure 1. Distribution of ICC and enteric nerves in the murine gastric fundus of wild type $(A-C)$ and $W / W^{v}$ mutants $(D-F)$. Kit-like immunoreactivity (Kit-LI; $A, C$; green) and vimentin-like immunoreactivity (Vim$L I ; B$; green) reveal IC-IM (arrows) within the circular muscle layer (single optical section $0.6 \mu \mathrm{m}$ thick in $z$-axis). Double-labeling immunohistochemical experiments using antibodies for the vesicular acetylcholine transporter ( $v A C h T-L I ; A$; red) and substance-P (Sub-P-LI; B; red) identify processes within the circular muscle (arrowheads) of enteric excitatory neurons. Nitric oxide synthase-like immunoreactivity (NOS-LI;C; red) identifies processes of inhibitory motor neurons within the circular muscle layer. Note the close apposition of IC-IM with varicose terminals of excitatory and inhibitory neurons. Individual nerve processes are associated with multiple IC-IM (asterisk). Excitatory and inhibitory neurons (arrowheads) within the gastric fundus of $W / W^{\mathrm{v}}$ mutants appeared normal (as labeled in $D-F ;$ red), but these tissues lacked IC-IM (note absence of green-labeled cells). Scale bar in $F$ applies to all panels. 

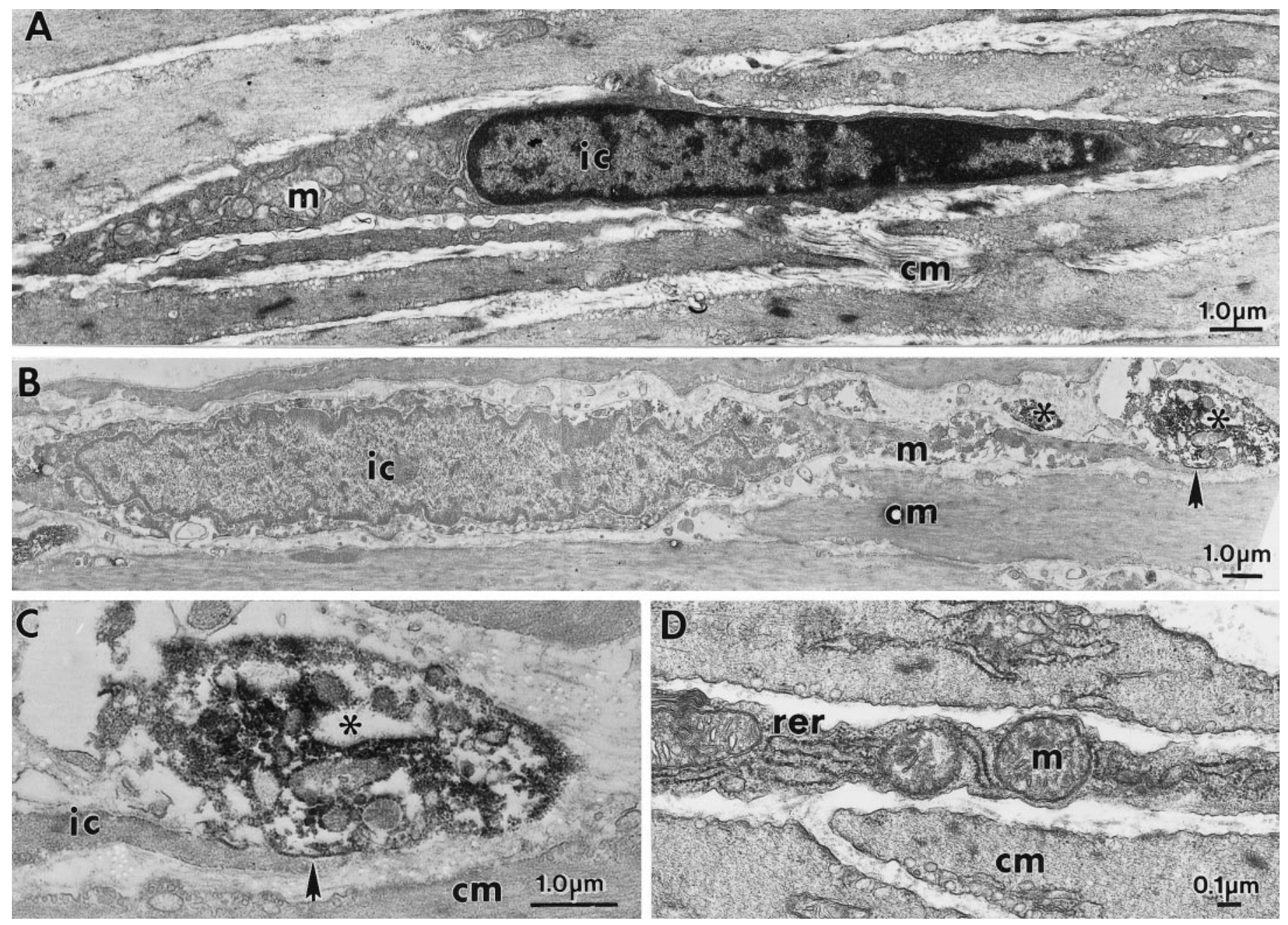

Figure 2. A, D, IC-IM and smooth muscle cells are of similar spindle-like shape in the circular muscle layer of the fundus. These cells have distinct ultrastructural features. IC-IM $(\mathrm{ic})$ contain numerous mitochondria $(\mathrm{m})$, smooth and rough endoplasmic reticulum, dense heterochromatic nuclei, and few myofilaments and dense bodies. Smooth muscle with typical ultrastructural features surrounds the IC-IM. IC-IM and enteric neurons with vAChT-LI form intimate contacts as revealed by immunoelectron microscopy. B, An IC-IM within the circular muscle layer ( $\mathrm{cm}$ ) is shown. Areas of close, synaptic-like structures (arrow) exist between vAChT-containing nerve terminals (asterisks) and IC-IM. $C$, The region denoted by the arrow in $B$ is shown in higher power.

layer; $p>0.05$ when compared with vAChT-like-immunoreactive bundles in the circular layer). Sub-P-immunoreactive nerve bundles were also seen in very close association with IC-IM (Fig. 1B) in both muscle layers and similar to vAChT-containing nerves; individual Sub-P-like-immunoreactive bundles were associated with several IC-IM.

Double-labeling experiments with NOS and Kit antibodies showed that the close morphological association between enteric nerves and IC-IM was not limited to excitatory neurons. The inhibitory motor neurons were also found in close association with IC-IM (Fig. 1C).

Similar double-labeling experiments were performed on fundus muscles from $W / W^{\mathrm{v}}$ mutants. These experiments revealed no significant differences in the distribution of excitatory and inhibitory nerve bundles within the circular and longitudinal muscle layers. For example, the numbers of vAChT, Sub-P, and NOS nerve bundles per $100 \mu \mathrm{m}$ cross section perpendicular to the circular muscle layer of $W / W^{\mathrm{v}}$ mutants were $5.7 \pm 2.0,5.18 \pm 2.8$, and $5.44 \pm 1.9$, respectively (Fig. $1 D-F ; n=10$ ); these were not statistically different when compared with the number of bundles in wild-type animals ( $p>0.05$ for all nerve types; see above). IC-IM were not found in the fundus of $W / W^{\mathrm{v}}$ mutant animals, as documented previously (Burns et al., 1996) (see Fig. 1D-F).

Although confocal microscopy revealed a close correlation between vAChT-LI, Sub-P-LI, and NOS-LI nerve bundles, evidence of direct innervation of IC-IM could not be obtained by light microscopy. Therefore, we conducted a series of ultrastructural studies to determine the nature of the morphological association between motor nerve endings and IC-IM.

Smooth muscle cells and IC-IM were of similar shape but displayed distinctly different ultrastructural features (Fig. 2A,D). By the use of immunoelectron microscopy, nerve fibers and varicosities immunoreactive for either vAChT or NOS were found within the circular and longitudinal muscle layers. It is likely that the majority of these fibers were nerve terminals of enteric motor neurons, and it is unlikely that vAChT immunoreactivity was caused by vagal efferent fibers because these neurons do not terminate within the muscle layers (Holst et al., 1997). vAChT immunoreactivity was associated with either the membranes or within the lumen of vesicles within varicosities. NOS immunore- 

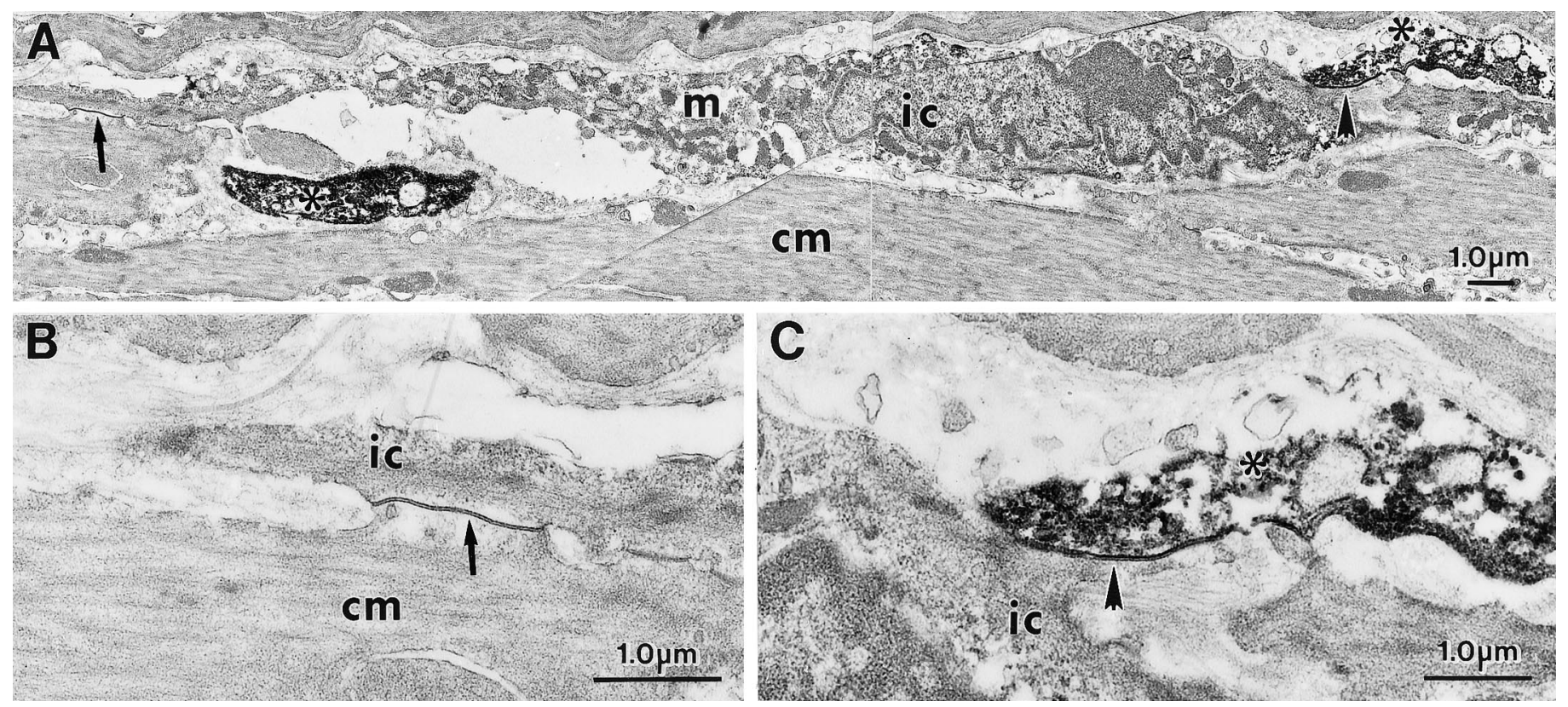

Figure 3. IC-IM and enteric neurons with NOS-LI form intimate contacts as revealed by immunoelectron microscopy. $A$, An IC-IM (ic) within the circular muscle layer $(\mathrm{cm})$ is shown. IC-IM were readily identified by the large number of mitochondria $(m)$, rough endoplasmic reticulum, and free ribosomes. NOS-LI in enteric nerve terminals is observed as a dense DAB reaction product (asterisk). $A$, $C$, A close, synaptic-like region of membrane exists between a NOS-LI nerve terminal and IC-IM (short arrow; at higher magnification in $C$ ). $A, B$, The IC-IM in $A$ also forms a gap junction with a neighboring smooth muscle cell (long arrow; at higher power in $B$ ).

activity was occasionally associated with the membranes of organelles or appeared as a more diff use labeling within varicosities (Figs. 2, 3). Numerous synaptic-like junctions were observed between vAChT-positive varicosities and IC-IM, with distances as little as $20 \mathrm{~nm}$ between these cells (Fig. 2B,C). Only occasional close contacts were observed between varicosities and circular smooth muscle cells (data not shown). Close contacts could also be found between NOS-positive fibers and IC-IM (Fig. 3A,C). IC-IM that formed synaptic-like junctions with NOS-positive fibers also formed gap junctions with neighboring smooth muscle cells (Fig. 3B). Thus, morphologically it appears that motor innervation in the murine fundus is primarily serial in nature, with IC-IM interposed between nerve endings and circular smooth muscle cells (Fig. 3).

\section{Postjunctional responses to neural stimulation are reduced in muscles of $W / W^{N}$ animals}

Electrical recordings, made from microelectrode impalements of cells within fundus muscles, showed that this region of the stomach lacked electrical slow waves in wild-type and mutant animals. No differences were detected in the resting membrane potentials of wild-type $(-46.8 \pm 0.9 \mathrm{mV} ; n=17)$ and $W / W^{\mathrm{v}}(-47.8 \pm 0.9$ $\mathrm{mV} ; n=13 ; p>0.05)$ fundus cells.

EFS of enteric neurons using single pulses $(0.5 \mathrm{msec}$ duration, supramaximal voltage) produced biphasic, tetrodotoxin-sensitive $(1 \mu \mathrm{M})$, postjunctional responses in circular muscles of wild-type animals. These responses were characterized by a rapid excitatory junction potential (EJP; average amplitude $=8.0 \pm 0.8 \mathrm{mV} ; n=$ 7), followed by an inhibitory junction potential (IJP; average amplitude $=6.9 \pm 0.6 \mathrm{mV} ; n=7)$. The nitric oxide synthase antagonist L-NA $(100 \mu \mathrm{M})$ caused depolarization of membrane potential $(3.7 \pm 0.8 \mathrm{mV} ; p<0.01)$ in wild-type tissues. The EJP component of the response to field stimulation was potentiated by L-NA (i.e., by $37 \%$ from $8.0 \pm 0.8$ to $11.1 \pm 0.8 \mathrm{mV} ; p<0.05$ compared with control), and the IJP component was reduced by $62 \%$ in amplitude and $40 \%$ in duration (i.e., from $6.9 \pm 0.6$ to $2.6 \pm 0.4 \mathrm{mV}$ and from $880 \pm 42$ to $530 \pm 30 \mathrm{msec}$, respectively; $p<0.001$ for changes in both parameters). The latter confirms that a significant component of the inhibitory response is caused by release of nitric oxide (see also Burns et al., 1996). The EJP component was cholinergic because it was completely blocked by atropine ( $1 \mu \mathrm{M} ; n=4$; Fig. $4 A-C)$.

In contrast to the stereotypical neural responses in wild-type animals, EFS (single pulses; $0.5 \mathrm{msec}$ in duration) of fundus muscles of $W / W^{\mathrm{v}}$ mutants produced greatly reduced responses (Fig. 4D-F). The average amplitude of the EJP component was $0.6 \pm 0.2 \mathrm{mV}$, and the IJP component averaged $1.53 \pm 0.6 \mathrm{mV}$ ( $n=6 ; p<0.05$ for both responses when compared with wildtype animals). L-NA $(100 \mu \mathrm{M})$ caused depolarization of circular muscle cells $(4.5 \pm 1.0 \mathrm{mV} ; p<0.01)$ but did not decrease IJPs. In fact we noted a small, but significant, increase in the amplitude of IJPs after L-NA in muscles of $W / W^{\mathrm{v}}$ mutants (from a control value of $1.5 \pm 0.6$ to $2.7 \pm 1.0 \mathrm{mV} ; p<0.05)$. EJPs were of negligible amplitude in $W / W^{\mathrm{v}}$ tissues after L-NA. These data are summarized in Figure 4, $G$ and $H$.

The magnitude of the excitatory responses depended on pulse duration. In wild-type muscles EJPs increased from $2.7 \pm 1.0 \mathrm{mV}$ with 0.1 -msec-duration pulses to $10.9 \pm 1.7 \mathrm{mV}$ at $0.75 \mathrm{msec}$ pulses $(n=6$; Fig. $5 A-C)$. EJPs in $W / W^{\mathrm{v}}$ muscles were of small amplitude at all stimulus strengths (i.e., $0.15 \pm 0.1 \mathrm{mV}$ at $0.1 \mathrm{msec}$ and $1.0 \pm 0.3 \mathrm{mV}$ at $0.75 \mathrm{msec} ; n=6$; Fig. $5 D-F)$. L-NA increased the amplitude of EJPs at all pulse durations in wild-type muscles but failed to increase EJPs in $W / W^{\mathrm{v}}$ muscles (i.e., $0.13 \pm 0.1 \mathrm{mV}$ at $0.1 \mathrm{msec}$ and $0.3 \pm 0.3 \mathrm{mV}$ at $0.75 \mathrm{msec})$. These data are summarized in Figure $5 G$.

Mechanical responses to nerve stimulation were also examined using muscles of wild-type and $W / W^{\mathrm{v}}$ animals. The amplitude of wild-type circular muscle contractions elicited by single pulses of 


$$
(+/+)
$$
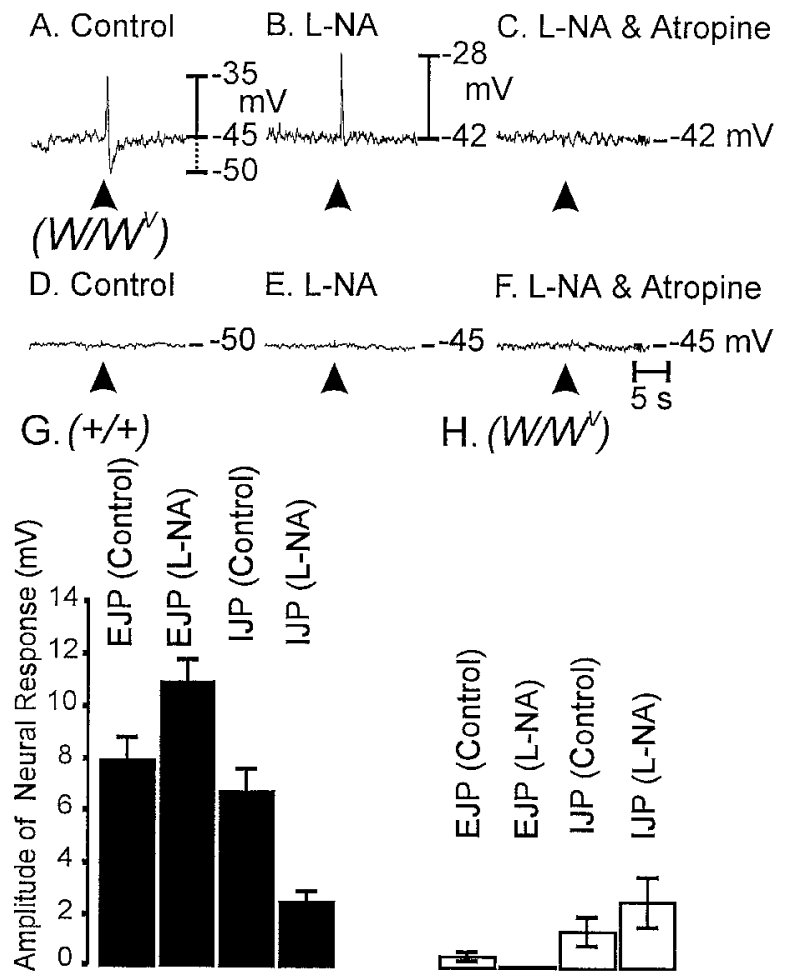

Figure 4. Differences in responses to EFS in wild-type and $W / W^{\mathrm{v}}$ mutant animals. $A$, EFS (arrowhead; 0.5 msec pulse supramaximal voltage) produced a biphasic electrical response in wild-type muscles, characterized by a rapid EJP. The EJP was followed by an IJP. $B$, L-NA $(100 \mu \mathrm{M})$ reduced the IJPs and increased the amplitudes of the EJPs. $C$, After L-NA, atropine $(1 \mu \mathrm{M})$ completely blocked the EJPs, suggesting that muscarinic receptors mediated the EJP responses. $D$, In $W / W^{\mathrm{v}}$ mutant animals, EJPs and IJPs were greatly attenuated. $E, F$, L-NA had little or no effect on responses to EFS $(E)$, and after L-NA, atropine had no effect $(F)$. $G, H$, The effects of L-NA on EJPs and IJPs from experiments on muscles of wild type $(n=17$; filled vertical bars $)$ and of $W / W^{\mathrm{v}}$ mutants ( $n=13$; open vertical bars) are summarized in $G$ and $H$, respectively.

EFS increased as a function of pulse duration (from $0.03 \pm 0.02$ $\mathrm{mN} / \mathrm{mg}$ with $0.1 \mathrm{msec}$ pulses to $0.77 \pm 0.1 \mathrm{mN} / \mathrm{mg}$ with $0.75 \mathrm{msec}$ pulses; $p<0.05$; $n=7$; Fig. $6 A-C)$. L-NA $(100 \mu \mathrm{M})$ increased basal tone in $33 \%$ of 12 wild-type muscle strips tested by an average of $2.1 \pm 0.3 \mathrm{mN}$. L-NA also increased the amplitudes of responses to EFS at all pulse durations. For example, the contractile response to stimulation with 0.75 -msec-duration pulses increased by $58 \%$ from $0.77 \pm 0.1$ to $1.22 \pm 0.12 \mathrm{mN} / \mathrm{mg}(p<0.05)$.

Contractile responses to EFS of muscles from $W / W^{\mathrm{v}}$ animals were significantly attenuated at all pulse durations tested (e.g., no resolvable responses were noted with $0.1 \mathrm{msec}$ pulses, and an average contraction of $0.27 \pm 0.05 \mathrm{mN} / \mathrm{mg}$ was elicited with 0.75 msec pulses; $n=5$; Fig. $6 D-F)$. L-NA increased basal tone in one of nine $W / W^{\mathrm{v}}$ muscles (by $0.5 \mathrm{mN}$ ) but did not increase the contractile responses to EFS at any pulse duration tested. Instead, L-NA caused attenuation of the contractile responses of $W / W^{\mathrm{v}}$ muscles to EFS. For example, L-NA reduced the contractile response elicited by $0.5 \mathrm{msec}$ pulses from $0.24 \pm 0.05$ to $0.12 \pm$ $0.02 \mathrm{mN} / \mathrm{mg}$. These data are summarized in Figure $6 G$.

\section{Effect of exogenous acetylcholine}

One explanation for the loss of cholinergic responses in muscles of $W / W^{\mathrm{v}}$ animals is a possible reduction in responsiveness to $\mathrm{ACh}$.

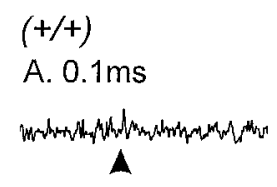

$\left(W W^{\prime \prime}\right)$

D. $0.1 \mathrm{~ms}$

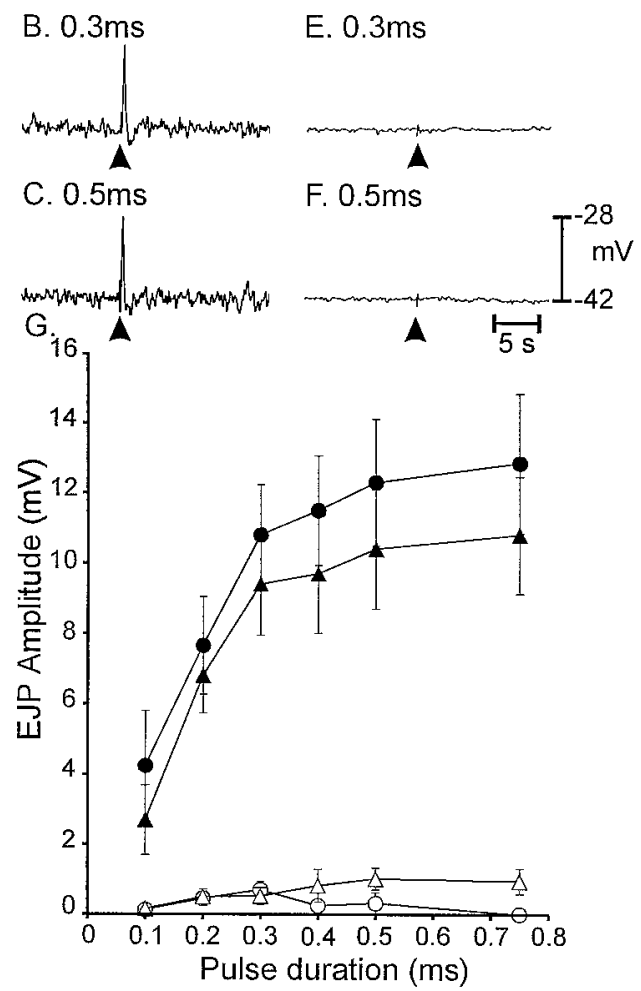

Figure 5. Pulses of EFS of different durations (0.1-0.75 msec) altered responses of gastric fundus muscles. $A-C$, Increasing the duration of pulses (arrowheads) potentiated the amplitude of EJPs in wild-type tissues ( $A-C$ for pulse durations of $0.1,0.3$, and $0.5 \mathrm{msec}$, respectively). $D-F$, EFS of the same pulse duration had no effect in $W / W^{\mathrm{v}}$ muscles $(D-F$ for pulses of $0.1,0.3$, and $0.5 \mathrm{msec}$, respectively). $G$, The electrical responses to EFS as a function of pulse duration in wild type before (filled triangles) and after ( filled circles) addition of L-NA $(100 \mu \mathrm{M})$ are summarized. Responses were greatly diminished in $W / W^{\mathrm{v}}$ muscles using the same stimulus parameters before (open triangles) and after (open circles) L-NA.

We tested this hypothesis by comparing responses to exogenous ACh in wild-type and $W / W^{\mathrm{v}}$ muscles. ACh $(0.01-10 \mu \mathrm{M})$ depolarized wild-type and $W / W^{\mathrm{v}}$ muscles in a concentrationdependent manner. The depolarization produced by acetylcholine was greater in $W / W^{\mathrm{v}}$ than in wild-type muscles. For example $0.3 \mu \mathrm{M}$ ACh depolarized wild-type muscles by $3.7 \pm 1.4 \mathrm{mV}$ (Fig. $7 A)$ and $W / W^{\mathrm{v}}$ muscles by $8.1 \pm 1.2 \mathrm{mV}(p>0.05$; Fig. $7 B) ; 1.0$ $\mu \mathrm{M}$ ACh depolarized wild-type muscles by $7.9 \pm 0.8 \mathrm{mV}$ (Fig. $7 C$ ) and $W / W^{\mathrm{v}}$ muscles by $11.5 \pm 1.1 \mathrm{mV}(p<0.05$; Fig. $7 D)$.

The effects of exogenous ACh $(0.01-10 \mu \mathrm{M})$ on mechanical activity were also tested in 15 tissues each from five wild-type and five $W / W^{\mathrm{v}}$ animals. ACh increased the basal tone of wild-type and $W / W^{\mathrm{v}}$ muscle strips in a dose-dependent manner (Fig. 7G). However, the nature of the contractile response was somewhat different in wild-type and $W / W^{\mathrm{v}}$ muscles (Fig. $7 E, F$ ). In $47 \%$ of wild-type and $92 \%$ of $W / W^{\mathrm{v}}$ muscles, phasic contractile activity was superimposed on the increase in basal tone. Thus, $W / W^{\mathrm{v}}$ muscles do not lose responsiveness to $\mathrm{ACh}$, and in fact, they experience a phenomenon similar to supersensitivity when innervation of IC-IM is lost. 
$(+/+)$

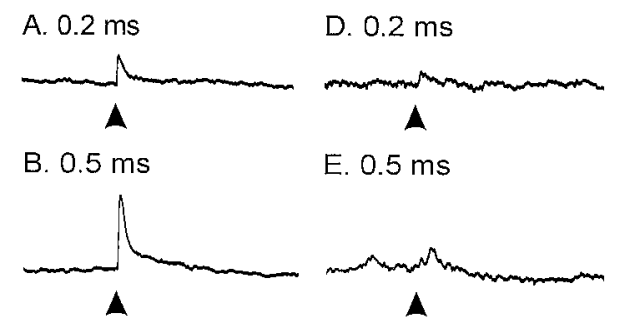

C. $0.75 \mathrm{~ms}$

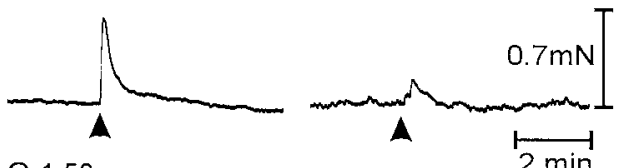

G. 1.50

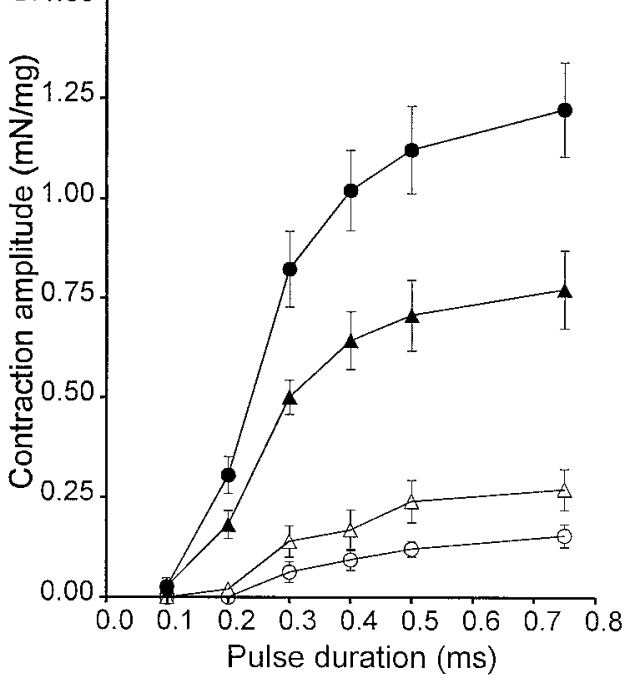

Figure 6. Mechanical responses to EFS in wild-type and mutant gastric tissues. $A-C$, Isometric contractions to single pulses of EFS (arrowheads; $0.1,0.5$, and $0.75 \mathrm{msec}$, respectively) are shown. $D-F$, Mechanical responses of a $W / W^{\mathrm{v}}$ muscle using the same stimulus parameters are shown. $G$, Mechanical responses to EFS of wild-type muscles before (filled triangles) and after ( filled circles) L-NA (100 $\mu \mathrm{M})$ are summarized. Responses of $W / W^{\mathrm{v}}$ muscles were greatly attenuated using EFS with the same stimulus parameters. A summary of responses of $W / W^{\mathrm{v}}$ muscles to EFS before (open triangles) and after (open circles) L-NA are shown.

\section{Cholinergic responses can be elicited in $W / W^{N}$ muscles when ACh breakdown is inhibited}

The reduction in cholinergic responses in $W / W^{\mathrm{v}}$ muscles could result from the absence of IC-IM in these tissues. Morphological studies described above showed a high degree of innervation of IC-IM by cholinergic motor neurons. Normal cholinergic responses may require the close associations between IC-IM and excitatory motor nerve endings. $W / W^{\mathrm{v}}$ muscles are responsive to $\mathrm{ACh}$, so it might be possible to unmask responses to excitatory nerve stimulation by inhibiting the breakdown of ACh by tissue cholinesterases. We tested this by treating muscles with neostigmine $(0.5 \mu \mathrm{M})$ to inhibit cholinesterases. In the presence of L-NA, neostigmine caused membrane depolarization of wild-type and $W / W^{\mathrm{v}}$ muscles. The circular muscle of wild-type animals depolarized by $2.5 \mathrm{mV}$ to an average of $-40.6 \pm 1.0 \mathrm{mV}$, and $W / W^{\mathrm{v}}$ muscles depolarized by $2.1 \mathrm{mV}$ to an average of $-41.2 \pm 1.7 \mathrm{mV}$ $(n=6)$. Neostigmine enhanced the amplitude of EJPs stimulated by pulse durations from 0.1 to $0.75 \mathrm{msec}$ in wild-type muscles. For example, EJPs elicited by $0.5 \mathrm{msec}$ pulse durations were increased by $30 \%$ (i.e., from $11.1 \pm 0.8$ to $14.4 \pm 0.8 \mathrm{mV} ; p<0.01$; Fig. $8 A$ ). These data suggest that endogenous cholinesterases normally degrade neurally released $\mathrm{ACh}$ and moderate excitatory responses. Neostigmine treatment also produced a secondary depolarization after the normal fast EJP in wild-type muscles. The secondary depolarization developed slowly and was more sustained in duration than was the control EJP. The amplitude of the secondary component increased as the pulse duration was increased from 0.1 to $0.75 \mathrm{msec}$. With a stimulus of $0.5 \mathrm{msec}$ the average amplitude and duration of the secondary depolarization were $8.3 \pm 0.4 \mathrm{mV}$ and $7.4 \pm 0.6 \mathrm{sec}$, respectively. Neostigmine did not unmask fast EJPs in muscles of $W / W^{\mathrm{v}}$ animals. However, in the presence of neostigmine EFS produced slow depolarization responses that were dependent on stimulus pulse duration (0.1-0.5 msec; Fig. 8B). These responses were similar to the secondary component of depolarization observed in wild-type animals after neostigmine (e.g., at pulse durations of $0.5 \mathrm{msec}$ the slow depolarization in $W / W^{\mathrm{v}}$ muscles averaged $9.3 \pm 0.8 \mathrm{mV}$ in amplitude and $9.8 \pm 0.8 \mathrm{sec}$ in duration). The slow depolarizations were abolished by atropine $(1 \mu \mathrm{M} ; n=3)$.

Neostigmine $(0.5 \mu \mathrm{M})$ increased the basal tone of circular muscles of wild-type $(4.0 \pm 0.4 \mathrm{mN})$ and $W / W^{\mathrm{v}}(4.1 \pm 0.9 \mathrm{mN})$ animals. Neostigmine also produced large increases in mechanical responses to nerve stimulation. For example, single pulses at $0.5 \mathrm{msec}$ duration caused contractile responses of $1.1 \pm 0.1$ $\mathrm{mN} / \mathrm{mg}$ (after treatment with L-NA) in wild-type muscles, and the response increased to $7.4 \pm 0.7 \mathrm{mN} / \mathrm{mg}$ in the presence of neostigmine and L-NA. In $W / W^{\mathrm{v}}$ muscles the responses increased from $0.1 \pm 0.02$ to $5.9 \pm 0.8 \mathrm{mN} / \mathrm{mg}$ in the presence of neostigmine ( $p>0.05$ for both increases in responses).

\section{Multiple-pulse stimulation}

The single-pulse EFS protocols and experiments with neostigmime described above suggested that fast, cholinergic EJPs cannot be elicited in $W / W^{\mathrm{v}}$ muscles. However, when ACh breakdown was inhibited, slow, cholinergic responses were resolved, suggesting that diff usion of transmitter through a larger volume can lead to interactions with muscarinic receptors expressed by smooth muscle cells. Further tests were performed to determine whether release of more transmitter can also accomplish direct smooth muscle stimulation. Multiple pulses of $\operatorname{EFS~(3,5,~and~10)~were~}$ delivered at high frequencies (30, 50, and $100 \mathrm{~Hz}$ ). EJPs evoked in wild-type muscles reached a maximum with five pulses at 50 $\mathrm{Hz}$ (i.e., $10.9 \pm 1.1 \mathrm{mV} ; n=5$; Fig. $9 A-D$ ). At higher frequencies EJPs were masked by overlapping IJPs. L-NA significantly attenuated the IJPs and increased EJPs at all frequencies (e.g., L-NA caused a $55 \%$ increase in EJP amplitude from $10.9 \pm 1.1$ to $16.9 \pm 1.2 \mathrm{mV}$ with five pulses at $50 \mathrm{~Hz} ; p<0.01)$. Under identical conditions, EFS failed to evoke EJPs in $W / W^{\mathrm{v}}(n=5$; Fig. $9 E-H)$.

\section{Studies to evaluate $\mathrm{ACh}$ release during EFS}

It is possible that trophic influences lost with IC-IM cause cholinergic nerves to release less transmitter in $W / W^{\mathrm{v}}$ muscles. Therefore, experiments were performed to measure ACh release in response to EFS in wild-type $(n=5$ experiments, 3 tissues from 3 animals used in each experiment) and $W / W^{\mathrm{v}}(n=5$ experiments, 3 tissues from 3 animals used in each experiment) muscles. EFS ( $60 \mathrm{~V}$; $0.3 \mathrm{msec}$ pulse duration at $5 \mathrm{~Hz}$ for $1 \mathrm{~min}$ ) of fundus tissues from wild-type animals caused an $\sim 400 \%$ increase in the fractional release of $\left[{ }^{14} \mathrm{C}\right]$ choline $(n=5$; Fig. $10 A)$. Release of $\left[{ }^{14} \mathrm{C}\right]$ choline was reduced in a reversible manner by tetrodo- 

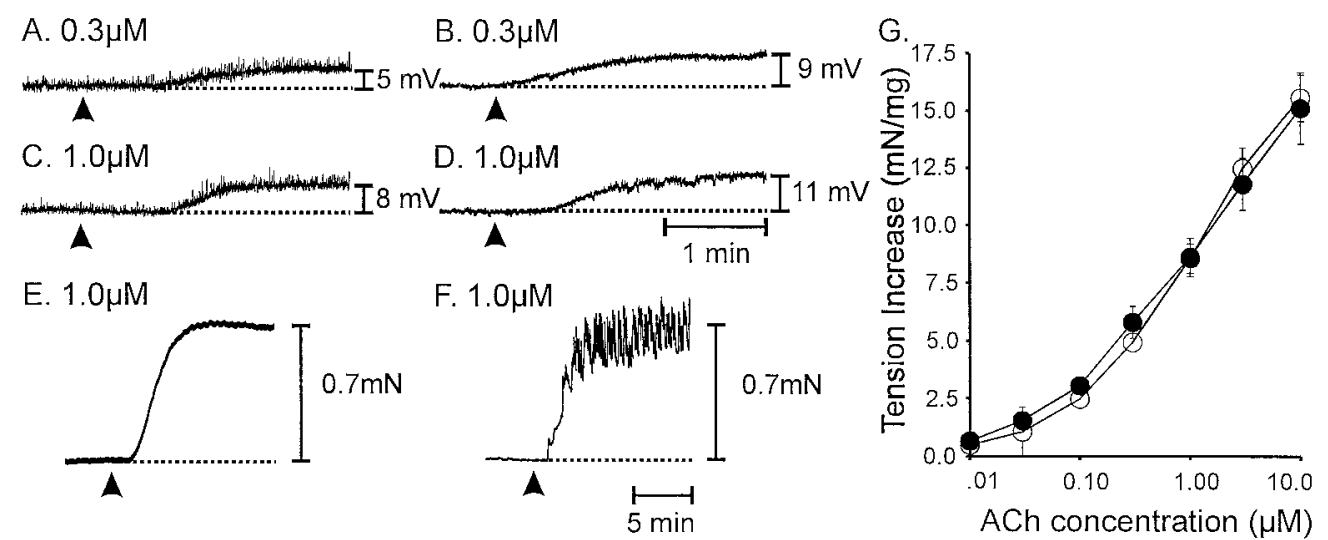

Figure 7. Electrical and mechanical responses of wild-type and $W / W^{\mathrm{v}}$ muscles to exogenous ACh. Application of ACh (arrowheads) tonically depolarized muscles in a concentration-dependent manner. $A$, $C$, Responses of wild-type muscles to 0.3 and $1.0 \mu \mathrm{M}$, respectively. $B, D$, Responses of $W / W^{\mathrm{v}}$ muscles to the same doses. Acetylcholine caused contractions of wild-type and $W / W^{\mathrm{v}}$ muscles. $E$, The mechanical response of a wild-type muscle to $1.0 \mu \mathrm{M}$ ACh. $F$, The response of a $W / W^{v}$ muscle to the same concentration of ACh. Many $W / W^{v}$ muscles displayed oscillations in tone superimposed on the tonic contraction. This type of response also occurred, but more rarely in wild-type muscles. $G$, A summary of the responses of wild-type (filled circles; $n=5)$ and $W / W^{\mathrm{v}}$ (open circles; $\left.n=5\right)$ muscles to ACh $(0.01-10 \mu \mathrm{M})$.

toxin $(1 \mu \mathrm{M} ; n=3$ control experiments; Fig. $10 B)$ and slightly increased (without reaching statistical significance; $p>0.05$ ) by neostigmine $(1 \mu \mathrm{M})$. L-NA had no significant effect on $\left[{ }^{14} \mathrm{C}\right]$ choline release (Fig. 10C). EFS of $W / W^{\mathrm{v}}$ muscles caused a similar magnitude of increase in $\left[{ }^{14} \mathrm{C}\right]$ choline $(n=5 ; p>0.05)$, and release of $\left[{ }^{14} \mathrm{C}\right]$ choline in these tissues was also slightly increased (but did not reach significance) by neostigmine $(0.5 \mu \mathrm{M}$; Fig. $10 D)$.

In the presence of L-NA and neostigmine, hexamethonium (300 $\mu \mathrm{M})$ decreased the release of $\left[{ }^{14} \mathrm{C}\right]$ choline in both wild-type and $W / W^{\mathrm{v}}$ tissues. This decrease was reversed by atropine, indicating that the presynaptic modulation mechanism is operative in both tissue types (data not shown).

\section{Whole-organ experiments}

The role of IC-IM in the gastric accommodation reflex was tested by comparing the effects of fluid infusion on gastric pressure in isolated stomachs from age-matched wild-type and $W / W^{\mathrm{v}}$ animals. A standard volume $(200 \mu \mathrm{l})$ of Krebs' solution was infused into the stomachs at different rates (1.01-20.28 $\left.\mu \mathrm{l} \mathrm{sec}^{-1}\right)$, and gastric pressure (centimeters of $\mathrm{H}_{2} \mathrm{O}$ ) was plotted as a function of infusion volume for each of five different infusion rates (three inf usions were performed at each rate, and the compliance curves were averaged). In the stomachs of wild-type animals, gastric pressure increased in a graded manner as a function of fluid volume and infusion rate (e.g., from $3.9 \pm 0.3 \mathrm{~cm} \mathrm{H}_{2} \mathrm{O}$ at $1.01 \mu \mathrm{l}$ $\mathrm{sec}^{-1}$ to $10.6 \pm 0.3 \mathrm{~cm} \mathrm{H}_{2} \mathrm{O}$ at $20.28 \mu \mathrm{l} \mathrm{sec}^{-1}$; Fig. 11C). Gastric pressure changes in response to fluid infusion were significantly reduced in $W / W^{\text {v }}$ (e.g., $2.4 \pm 0.5 \mathrm{~cm} \mathrm{H}_{2} \mathrm{O}$ at $1.01 \mu \mathrm{l} \mathrm{sec}{ }^{-1}$ and $3.3 \pm 0.3 \mathrm{~cm} \mathrm{H}_{2} \mathrm{O}$ at $20.28 \mu \mathrm{l} \mathrm{sec}{ }^{-1} ; p>0.05$ when compared with controls; Fig. 11D). The effects of atropine and L-NA were tested on gastric pressure and the response to fluid infusion. Atropine $(1.0 \mu \mathrm{M})$ in the presence of L-NA $(100 \mu \mathrm{M})$ decreased gastric pressure in wild type (Fig. 11E) but produced little or no effect on gastric compliance in $W / W^{\mathrm{v}}$ animals (Fig. $11 F$ ).

\section{DISCUSSION}

The classical view of autonomic innervation is that the junction between nerve terminals and smooth and cardiac muscle is not a

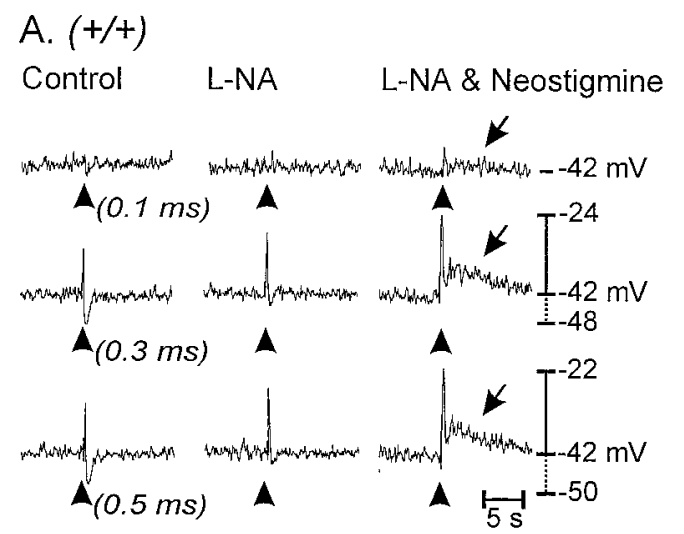

\section{B. $\left(W W^{2}\right)$}

Control L-NA L-NA \& Neostigmine
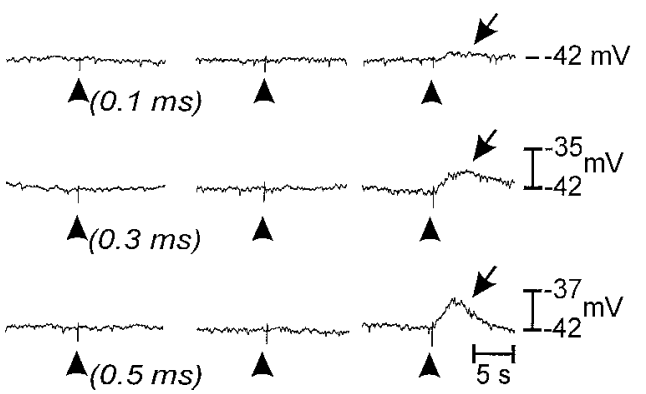

Figure 8. Inhibition of endogenous cholinesterase with neostigmine revealed a slowly developing membrane depolarization in wild-type and $W / W^{\mathrm{v}}$ mutant tissues. $A$, The electrical responses of wild-type muscles to EFS (arrowheads; single pulses of $0.1,0.3$, and $0.5 \mathrm{msec}$ duration) before (left) and after (middle) L-NA $(100 \mu \mathrm{M})$ and after L-NA with neostigmine $(0.5 \mu \mathrm{M} ;$ right $)$ are shown. L-NA blocked IJPs and potentiated EJPs. In the presence of L-NA, neostigmine increased the amplitude of the fast EJP and revealed a slowly developing, second depolarization (arrows). B, Responses of $W / W^{\mathrm{v}}$ muscles to EFS were negligible under control conditions (left) and after L-NA (middle). However, neostigmine added after L-NA revealed a slowly developing membrane depolarization in response to EFS (right) that was similar in detail and time course to the second depolarization response of wild-type muscles (arrows). 


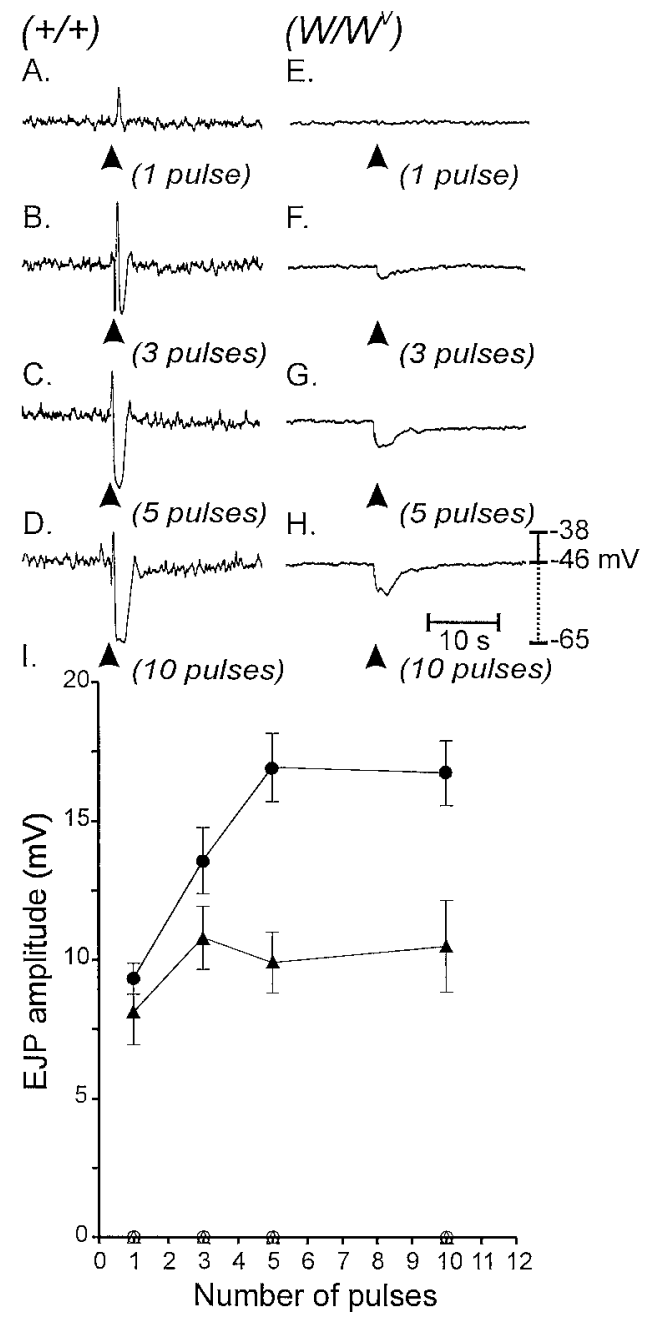

Figure 9. Electrical responses of wild-type and $W / W^{\mathrm{v}}$ muscles to EFS. $A-D$, Multiple pulses of EFS (arrowheads; 1-10 pulses delivered within $100 \mathrm{msec}$ ) caused pronounced EJPs and IJPs in wild-type muscles (1-10 pulses as labeled). $E-H$, EJPs were not observed in $W / W^{\mathrm{v}}$ muscles; however 3-10 pulses (delivered within $100 \mathrm{msec}$ ) caused slowly developing hyperpolarization responses in these tissues. L-NA had no effect on the IJPs elicited in $W / W^{\mathrm{v}}$ muscles with 3 or more pulses. $I$, Data for the effect of L-NA on control and $W / W^{\mathrm{v}}$ mutant tissues are summarized. EJPs elicited in wild-type muscles (filled triangles) were potentiated by L-NA (100 $\mu \mathrm{M}$; filled circles), whereas EJPs were absent in $W / W^{\mathrm{v}}$ muscles (open triangles) and not revealed by L-NA (open circles).

well defined structure (Burnstock, 1981). Instead some investigators have suggested that transmitter is released en passage as action potentials conduct down axons, and innervation is defined by the volume through which a transmitter can diffuse and still reach postjunctional receptors at an effective concentration. This concept has been challenged by recent studies using serialsectioning techniques and electron microscopy that have shown that distinct neuromuscular junctions are present in autonomically innervated tissues; however the structure of these junctions is less well defined than is that of skeletal neuromuscular junctions (Luff et al., 1987; Gabella, 1995). The present study suggests that close contacts between motor neurons and postjunctional cells are an important feature of enteric neurotransmission. With the present study we have provided morphological and functional data supporting the hypothesis that cholinergic neurotransmission depends to a significant degree on synaptic junctions be-
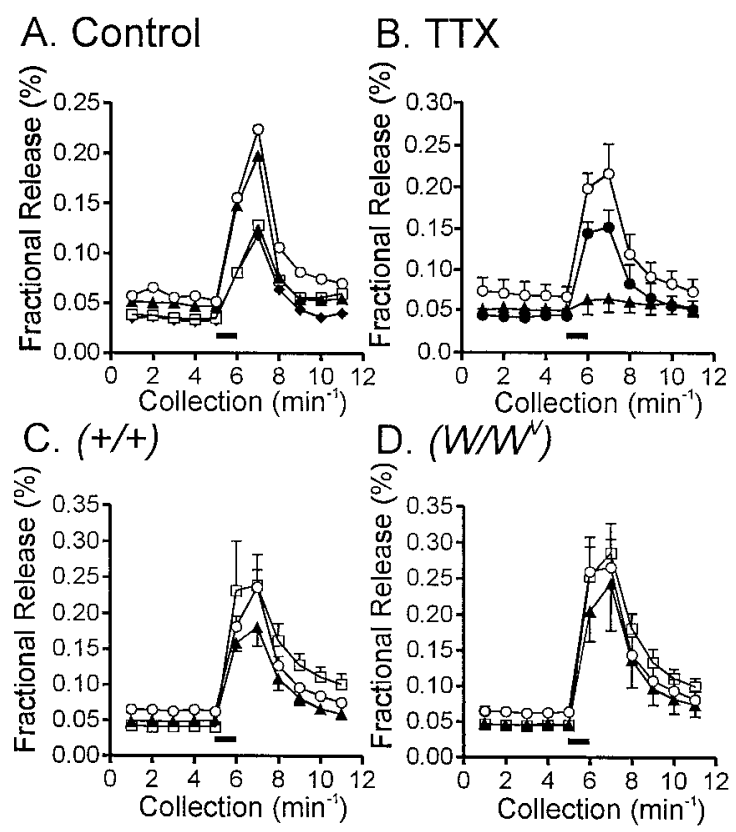

Figure 10. $\quad\left[{ }^{14} \mathrm{C}\right]$ Choline release from wild-type and $W / W^{\mathrm{v}}$ muscles in response to EFS. $A$, The typical $\left[{ }^{14} \mathrm{C}\right]$ choline overflow from a wild-type fundus muscle in response to EFS is shown. Tissues were stimulated at 40 min intervals for $1 \mathrm{~min}(5 \mathrm{~Hz}$; 0.1-msec-duration pulses; filled horizontal bar), and $\left[{ }^{14} \mathrm{C}\right]$ choline overflow was assayed from superfusion samples. $\left[{ }^{14} \mathrm{C}\right]$ Choline overflow is plotted as a percentage of fractional release with time of collection. Overflow decreased with subsequent stimulations $\left(\mathrm{S}_{1}\right.$, discarded; $\mathrm{S}_{2}$, open circles; $\mathrm{S}_{3}$, filled triangles; $\mathrm{S}_{4}$, open squares; $\mathrm{S}_{5}$, filled diamonds). $B$, The overflow of $\left[{ }^{14} \mathrm{C}\right]$ choline in response to EFS (open circles) was inhibited by TTX ( $1 \mu \mathrm{M} ; n=9$ tissues of 3 animals; filled triangles), and this was reversible after washout ( filled circles). $C, D$, EFS caused release of similar amounts of $\left[{ }^{14} \mathrm{C}\right]$ choline from wild-type $(C)$ or $W / W^{\mathrm{v}}(D)$ muscles $(p>0.05)$. $\left[{ }^{14} \mathrm{C}\right]$ Choline release under control conditions (open circles, $\mathrm{S}_{2}$ ) was not affected by L-NA $(100 \mu \mathrm{M}$; filled triangles, $\left.\mathrm{S}_{3}\right)$ but was slightly increased by neostigmine $\left(0.5 \mu \mathrm{M}\right.$; open squares, $\left.\mathrm{S}_{4}\right)$.

tween motor neurons and specific classes of ICC in gastrointestinal muscles.

Cholinergic neuromuscular transmission in autonomically innervated muscles, such as the GI tract, has been thought to occur via release of $\mathrm{ACh}$, diffusion of the transmitter through a loosely defined postjunctional volume, and binding and activation of muscarinic receptors expressed by smooth muscle cells (Burnstock, 1981). The postjunctional responses (EJPs) elicited in smooth muscle cells exposed to sufficient amounts of ACh were thought to elicit depolarization responses in neighboring, possibly noninnervated, smooth muscle cells via gap junctions. The findings of the present study suggest this concept is incomplete, and an alternative model that extends the concept first proposed by Ramon y Cajal (1911) and later by Roman et al. (1975) and Daniel and Posey-Daniel (1984) is more consistent with our data; $\mathrm{ACh}$, released from enteric motor neurons, binds primarily to receptors expressed by ICC. Activation (depolarization) of neighboring smooth muscle cells occurs by conduction of EJPs via gap junctions between ICC and smooth muscle cells. Thus, terminals of enteric motor neurons, IC-IM, and smooth muscle cells form functional units that release transmitter and mediate and transduce neural inputs into mechanical responses. IC-IM seem to be a critical component in these functional units. The physically close association between varicose nerve terminals and ICC suggests that neuro-ICC junctions may be the primary sites of cholinergic innervation. Because the distances between cholinergic 


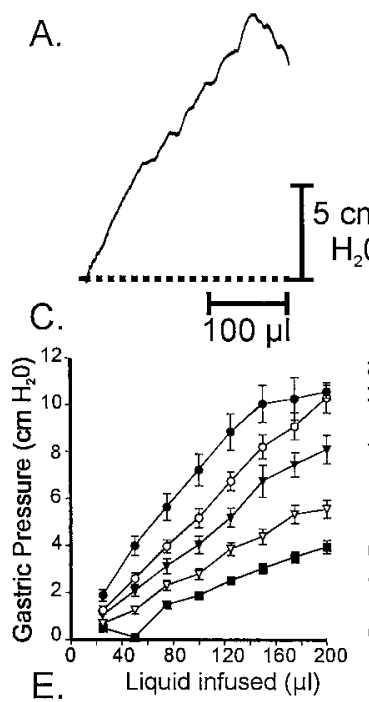

B.
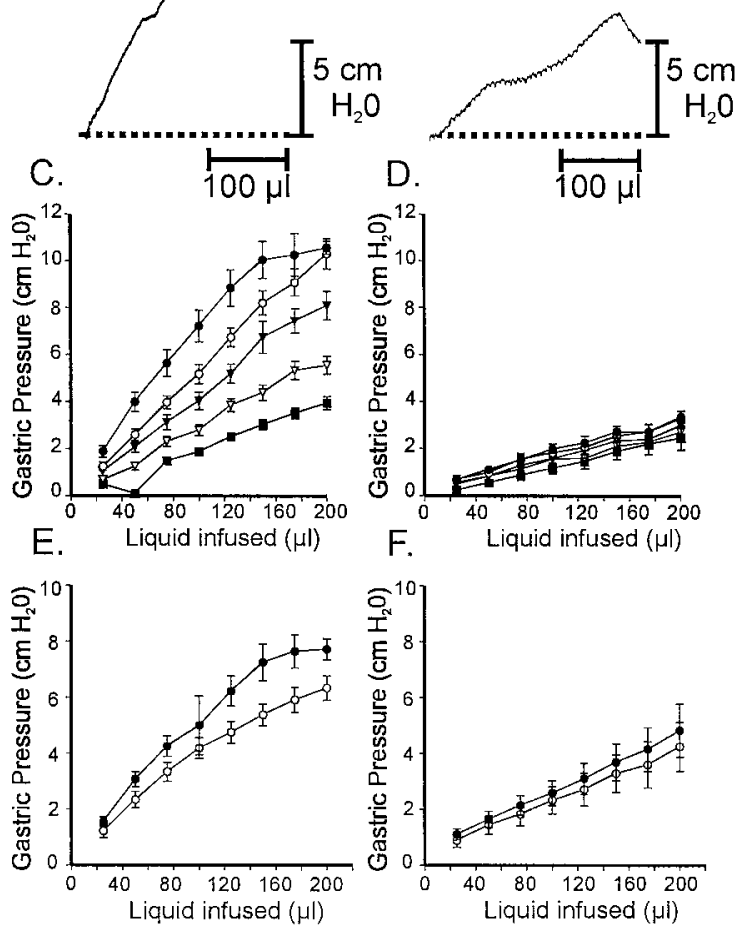

Figure 11. Gastric compliance measurements from ex vivo stomachs of wild-type and $W / W^{\mathrm{v}}$ animals. Gastric pressure (centimeters of $\mathrm{H}_{2} \mathrm{O}$ ) was recorded as a function of constant volume infusions at rates varying from 1.01 to $20.28 \mu \mathrm{lsec}^{-1}$. Three infusions were performed at each rate, and the data were averaged (30-d-old age-matched animals; $n=5$ for each genotype). $A$, Gastric pressure increased as fluid was infused in the stomachs of wild-type animals. The gastric pressure response increased as a function of infusion rate. $B$, Gastric pressure responses to fluid inf usion were greatly diminished in the stomachs of $W / W^{\mathrm{v}}$ mutants $(p<0.05$ when compared with wild-type stomachs). $C, D$, Summary data from five wild-type animals $(C)$ and five $W / W^{\mathrm{v}}$ mutants $(D)$ are shown $(1.01 \mu \mathrm{l}$ $\mathrm{sec}^{-1}$, filled squares; $2.02 \mu \mathrm{l} \mathrm{sec}{ }^{-1}$, open inverted triangles; $4.09 \mu \mathrm{l} \mathrm{sec}^{-1}$, filled inverted triangles; $8.21 \mu \mathrm{l} \mathrm{sec}{ }^{-1}$, open circles; $20.28 \mu \mathrm{l} \mathrm{sec}{ }^{-1}$, filled circles). $E, F$, Atropine $(1 \mu \mathrm{M})$ in the presence of L-NA $(100 \mu \mathrm{M})$ increased gastric compliance of wild-type stomachs $(E)$ but had little or no effect on the stomachs of $W / W^{\mathrm{v}}$ animals ( $F$; L-NA, filled circles; L-NA and atropine, open circles for both $E, F$ ).

varicosities and ICC are small $(<20 \mathrm{~nm})$, diffusion and postjunctional responses are rapid (latency of fast $\mathrm{EJP}=78 \pm 13 \mathrm{msec}$ ), and the characteristic response to cholinergic transmission in muscles of normal animals is a fast EJP that couples to a contractile response. Overflow of ACh from neuro-ICC junctions seems to be limited by local acetylcholinesterase activity, and the apparently high metabolic capability of these enzymes tends to restrict $\mathrm{ACh}$ released from nerve terminals to a relatively small volume of influence. Inhibition of acetylcholinesterase appears to increase the overflow of $\mathrm{ACh}$, resulting in direct smooth muscle responses. The smooth muscle responses occurred after longer latencies and with slower kinetics than did the responses attributed to innervation of ICC. Thus IC-IM, because of the close contacts these cells form with excitatory motor neurons, mediate primary cholinergic innervation in the murine fundus. Although our functional experiments demonstrated little evidence of direct cholinergic innervation of smooth muscle cells, it is possible that parallel innervation of the smooth muscle may also occur (1) through relatively more rare direct junctions between motor neurons and smooth muscle cells, (2) by ACh overflow from neuro-ICC junctions during sustained high-frequency nerve stimulation, or (3) by recruitment of peptide transmitters at higher frequencies of stimulation that may have larger volumes of influence because of slower rates of metabolism.

One interpretation of our results could be that trophic influences lost with IC-IM in $W / W^{\mathrm{v}}$ mutants might alter neuronal release of transmitter or the postjunctional response of smooth muscle cells. We tested these possibilities by measuring the density of innervation by $\left[{ }^{14} \mathrm{C}\right]$ choline release of cholinergic neurons during EFS of muscles from wild-type and mutant animals. Loss of IC-IM affected neither the distribution of excitatory motor neurons nor the amount of ACh released during EFS. Postjunctional responses to exogenous $\mathrm{ACh}$ were intact in the muscles of $W / W^{\mathrm{v}}$ animals, suggesting that the reduction in cholinergic responses was not caused by loss of muscarinic receptors or cellular effectors in smooth muscle cells. The development of responses to nerve stimulation in $W / W^{\mathrm{v}}$ muscles in the presence of neostigmine suggests that cholinergic, receptor-mediated mechanisms of smooth muscle cells are intact in these animals. Thus, the defects observed in the postjunctional responses of $W / W^{\mathrm{v}}$ muscles to enteric nerve stimulation are likely to be attributable to physical and functional denervation caused by the absence of IC-IM.

The observation that tissues of $W / W^{\mathrm{v}}$ animals retain responsiveness to exogenous ACh contrast with the effects of losing IC-IM on NO-dependent inhibitory responses (Burns et al., 1996; Ward et al., 1998). In those studies, tissues of $W / W^{\mathrm{v}}$ animals lost electrical responsiveness to exogenous NO, suggesting that IC-IM express critical transduction mechanisms or ionic conductances that mediate postjunctional inhibitory responses. Responsiveness to exogenous ACh was not lost in $W / W^{\mathrm{v}}$ muscles, confirming that smooth muscle cells also express the muscarinic receptors and ionic conductances necessary to mediate postjunctional responses. Thus, loss of responsiveness to cholinergic nerve stimulation in tissues without IC-IM seems to be primarily caused by loss of the close association between motor neurons and postjunctional receptors expressed by IC-IM. Close contacts seem to be an important feature of enteric cholinergic neuromuscular transmission because our data suggest that ACh released from nerve terminals is confined to a relatively small extracellular volume by endogenous acetylcholinesterase. IC-IM, by forming synaptic structures with excitatory motor neurons, provide the close associations required for efficient neurotransmission.

It should be noted that although responses to exogenous $\mathrm{ACh}$ were maintained in $W / W^{\mathrm{v}}$ muscles, the responses were somewhat altered in these tissues. ACh elicited tonic depolarization of membrane potential in wild-type muscles, but often ACh responses were characterized by oscillations in membrane potential and contractile activity in $W / W^{\mathrm{v}}$ tissues. Thus, it is possible that an ionic conductance, possibly a $\mathrm{K}^{+}$conductance expressed by IC-IM, serves to moderate cholinergic responses of the IC-IM/ smooth muscle syncytium and dampens the tendency for membrane potential to oscillate.

The role of IC-IM in excitatory motor nerve responses is potentially important in the pathophysiology of GI motility disorders. Several studies have shown loss of ICC in patients with a range of motility dysfunctions, including achalasia (FaussonePellegrini and Cortesini, 1985), pyloric stenosis (Vanderwinden et al., 1996), and pseudo-obstruction (Isozaki et al., 1997). Gastric compliance is regulated by neural inputs and possibly by stretchsensitive mechanisms expressed by smooth muscle cells or ICC. 
We found that both nitrergic and cholinergic inputs are factors in regulating normal compliance and the response to filling. Loss of IC-IM in the murine stomach caused a significant increase in gastric compliance, such that little or no pressure change was observed when the stomachs of these animals were perfused with fluid. This effect could be attributable to the loss in cholinergic tone that would be likely to accompany the loss of IC-IM. The gastric compliance in $W / W^{\mathrm{v}}$ animals was greater than the increase in compliance when muscarinic receptors were blocked in wildtype animals, suggesting that factors other than cholinergic tone contribute to gastric tone (i.e., other excitatory peptide neurotransmitters or the stretch sensitivity of IC-IM). Abnormal compliance is observed in some human gastric disorders (Salet et al., 1998), and it is would be interesting to determine whether these patients have defects in the numbers or function of IC-IM.

\section{REFERENCES}

Alberts P, Bartfai T, Stjarne L (1982) The effects of atropine on [3H]acetylcholine secretion from guinea-pig myenteric plexus evoked electrically or by high potassium. J Physiol (Lond) 329:93-112.

Burns AJ, Lomax AE, Torihashi S, Sanders KM, Ward SM (1996) Interstitial cells of Cajal mediate inhibitory neurotransmission in the stomach. Proc Natl Acad Sci USA 93:12008-12013.

Burnstock G (1981) Review lecture. Neurotransmitters and trophic factors in the autonomic nervous system. J Physiol (Lond) 313:1-35.

Daniel EE, Posey-Daniel V (1984) Neuromuscular structures in opossum esophagus: role of interstitial cells of Cajal. Am J Physiol 246:G305-G315.

Faussone-Pellegrini MS, Cortesini C (1985) The muscle coat of the lower esophageal sphincter in patients with achalasia and hypertensive sphincter. An electron microscopic study. J Submicrosc Cytol 17:673-685.

Gabella G (1995) The structural relations between nerve fibres and muscle cells in the urinary bladder of the rat. J Neurocytol 24:159-187.

Grady EF, Baluk P, Bohm S, Gamp PD, Wong H, Payan DG, Ansel J, Portbury AL, Furness JB, McDonald DM, Bunnett NW (1996) Characterization of antisera specific to NK1, NK2, and NK3 neurokinin receptors and their utilization to localize receptors in the rat gastrointestinal tract. J Neurosci 16:6975-6986.

Holst MC, Kelly JB, Powley TL (1997) Vagal preganglionic projections to the enteric nervous system characterized with Phaseolus vulgarisleucoagglutinin. J Comp Neurol 381:81-100.

Huizinga JD, Thuneberg L, Kluppel M, Malysz J, Mikkelsen HB, Bernstein A (1995) W/kit gene required for interstitial cells of Cajal and for intestinal pacemaker activity. Nature 373:347-349.

Isozaki K, Hirota S, Miyagawa J, Taniguchi M, Shinomura Y, Matsuzawa Y (1997) Deficiency of c-kit + cells in patients with a myopathic form of chronic idiopathic intestinal pseudo-obstruction. Am J Gastroenterol 92:332-334.

Klemm MF (1995) Neuromuscular junctions made by nerve fibres supplying the longitudinal muscle of the guinea-pig ileum. J Auton Nerv Syst 55:155-164.

Lavin ST, Southwell BR, Murphy R, Jenkinson KM, Furness JB (1998) Activation of neurokinin 1 receptors on interstitial cells of Cajal of the guinea-pig small intestine by substance P. Histochem Cell Biol 110:263-271.

Luff SE, McLachlan EM, Hirst GD (1987) An ultrastructural analysis of the sympathetic neuromuscular junctions on arterioles of the submucosa of the guinea pig ileum. J Comp Neurol 257:578-594.

Maeda H, Yamagata A, Nishikawa S, Yoshinaga K, Kobayashi S, Nishi K, Nishikawa S (1992) Requirement of c-kit for development of intestinal pacemaker system. Development 116:369-375.

Ordog T, Ward SM, Sanders KM (1999) Interstitial cells of Cajal generate and propagate electrical slow waves in the murine stomach. J Physiol (Lond) 518:257-269.

Portbury AL, Furness JB, Young HM, Southwell BR, Vigna SR (1996) Localisation of NK1 receptor immunoreactivity to neurons and interstitial cells of the guinea-pig gastrointestinal tract. J Comp Neurol 367:342-351.

Ramon y Cajal S (1911) Histologie du système nerveux de l'homme et des vertébrés, Vol 2, pp 891-942. Paris: Maloine.

Roman C, Gonella J, Niel JP, Condamin M, Miolan JP (1975) Effets de la stimulation vagale et de L'adrenaline sur la musculeuse lisse du bas oesophage du chat. INSERM 50:415-422.

Salet GA, Samsom M, Roelofs JM, van Berge Henegouwen GP, Smout AJ, Akkermans LM (1998) Responses to gastric distension in functional dyspepsia. Gut 42:823-829.

Sanders KM (1996) A case for interstitial cells of Cajal as pacemakers and mediators of neurotransmission in the gastrointestinal tract. Gastroenterology 111:492-515.

Somogyi P, Takagi H (1982) A note on the use of picric acidparaformaldehyde-glutaraldehyde fixative for correlated light and electron microscopic immunocytochemistry. Neuroscience 7:1779-1783.

Sternini C, Su D, Gamp PD, Bunnett NW (1995) Cellular sites of expression of the neurokinin-1 receptor in the rat gastrointestinal tract. J Comp Neurol 358:531-540.

Torihashi S, Ward SM, Nishikawa S, Nishi K, Kobayashi S, Sanders KM (1995) c-kit-dependent development of interstitial cells and electrical activity in the murine gastrointestinal tract. Cell Tissue Res 280:97-111.

Torihashi S, Nishi K, Tokutumi Y, Nishi T, Ward SM, Sanders KM (1999) Blockade of Kit signaling induces transformation of interstitial cells of Cajal to smooth muscle phenotype. Gastroenterology 117:140-148.

Vanderwinden JM, Liu H, de Laet MH, Vanderhaeghen JJ (1996) Study of the interstitial cells of Cajal in infantile hypertrophic pyloric stenosis. Gastroenterology 111:279-288.

Vannucchi MG, de Giorgio R, Faussone-Pellegrini MS (1997) NK1 receptor expression in the interstitial cells of Cajal and neurons and tachykinins distribution in rat ileum during development. J Comp Neurol 383:153-162.

Wang X-Y, Sanders KM, Ward SM (1999) Intimate relationship between interstitial cells of Cajal and enteric nerves in the guinea-pig small intestine. Cell Tissue Res 295:247-256.

Ward SM, Burns AJ, Torihashi S, Sanders KM (1994) Mutation of the proto-oncogene c-kit blocks development of interstitial cells and electrical rhythmicity in murine intestine. J Physiol (Lond) 480:91-97.

Ward SM, Harney SC, Bayguinov YJ, Sanders KM (1997) Development of electrical rhythmicity in the gastrointestinal tract is specifically encoded in the tunica muscularis. J Physiol (Lond) 505:241-258.

Ward SM, Morris G, Reese L, Wang X-Y, Sanders KM (1998) Interstitial cells of Cajal mediate enteric inhibitory neurotransmission in the lower esophageal and pyloric sphincters. Gastroenterology 115:314-329.

Young HM, Ciampoli D, Southwell BR, Newgreen DF (1996) Origin of interstitial cells of Cajal in the mouse intestine. Dev Biol 180:97-107. 